\title{
Isolation and Partial Characterization of Surface Producing Bacterial Strain Producing Amylase from Soil
}

\author{
Samriti Sharma ${ }^{1 *}$, Shiwani Guleria ${ }^{2}$, Arvind Behl ${ }^{3}$ and Navneet Batra ${ }^{3}$
}

${ }^{1}$ Dept. of Biotechnology, Dr Y S P University of Horticulture and Forestry Nauni, Solan, Himachal Pradesh (171 205), India

${ }^{2}$ Dept. of Microbiology, Lovely Professional University, Jalandher, Punjab (144 402), India

${ }^{3}$ Dept. of Biotechnology, GGDSD College, Chandigarh, Punjab (160 031), India

\section{Corresponding Author}

Samriti Sharma

e-mail: 1992samritisharma@gmail.com
Article History

Article ID: 3 C0956

Received in $02^{\text {nd }}$ November, 2017

Received in revised form $27^{\text {th }}$ December, 2017

Accepted in final form $29^{\text {th }}$ January, 2018

\begin{abstract}
Starch is an important constituent of the human diet and is a major storage product of many economically important crops such as wheat, rice, maize, tapioca, and potato. The production of $\alpha$-amylase is essential for conversion of starches into oligosaccharides. Amylase is one of the most important enzymes used in industry such as in textile, food, paper and pharmaceutical industry etc. Amylase has ability to hydrolyzed starch molecules into polymer composed of glucose unit. The aim of present study was to isolate amylase producing bacteria from soil samples, screening of amylase producing strains, morphological and biochemical characterizations of strains, and optimized cultural conditions of the strains. The soil samples were collected from deep soil of campus at Chandigarh with the help of aseptic spectula. The bacterial strains were isolated by serial dilution and plating method. Three bacterial strains such as RT03, RT5 and T5 having amylolytic activity was isolated. Based on intensity of clear zone one strain were selected for further study. The morphological characterization of strain RT5 showed that it is rod shaped bacilli, cream color, raised elevation, entire margin, moderate size and Gram negative in nature. Enzymatic activity of strain RT5 was estimated at various $\mathrm{pH}(6,7$ and 8$)$ and temperatures $\left(30^{\circ} \mathrm{C}, 37^{\circ} \mathrm{C}, 50^{\circ} \mathrm{C}\right.$ and $\left.60^{\circ} \mathrm{C}\right)$. The best amylolytic activity of RT5 was observed at $\mathrm{pH} 6$ with optimum temperature $50^{\circ} \mathrm{C}$.
\end{abstract}

Keywords: Amylase, bacterial strain enzyme, morphological characters, $\mathrm{pH}$

\section{Introduction}

Amylase is one of the most important industrial enzymes that have been used in biotechnology process particularly in starch hydrolysis (Kumar et al., 2013). Amylase is an extracellular enzyme which hydrolysed internal $\alpha 1$,4- glucan links of starch into dextrin and other small polymers which is made up of glucose unit (Behal et al., 2006). Starch is a complex carbohydrate made up of amylose and amylopectin (Singh et al., 2014). The concentration of amylose and amylopectin in starch ranged from $20-25 \%$ and $75-80 \%$ respectively depending upon the plant. Greatest application of this enzyme is in formation glucose and fructose syrups, detergent, sweetner, in paper industry, textile industry, food industry, fermentation industry, digestive aid and spot remover in dry cleaning (Sani et al., 2014; Singh et al., 2011). This enzyme is mainly derived from the microorganism, higher plants and animals. Microbial production of amylase reduced the use of chemical for the hydrolysis of starch in starch processing industry (Dehkordi et al., 2012). The $\alpha$-amylase is an metalloenzyme which are unable to do their function in the absence of $\mathrm{Mn}^{2+}$ and $\mathrm{Ca}^{2+}$ (Annamalai et al., 2011; Raul et al., 2014). They belong to family $13(\mathrm{GH}-13)$ of the glycoside hydrolase group of enzymes (Sivaramakrishnan et al., 2006). The amylase mainly the $\alpha$ amylase is present in salivary and pancreas of human. The $\alpha$ - amylase has a ability to act at any position of substrate thats by it act faster than that of $\beta$-amylase (Singh et al., 2011). The $\alpha$-amylase family can roughly be divided into two groups: the starch hydrolyzing enzymes and the starch modifying, or transglycosylating enzymes. The enzymatic hydrolysis is preferred to acid hydrolysis in starch processing industry due to a number of advantages such as specificity of the reaction, stability of the generated products, lower energy requirements and elimination of neutralization steps (Sivaramakrishnan et al., 2006). Due to the increasing demand for these enzymes in various industries, there is enormous interest in developing enzymes with better properties such as raw starch degrading amylases suitable for industrial applications and their cost effective production techniques. 


\section{Materials and Methods}

\subsection{Sample collection}

The soil samples were collected from 3-4 cm deep soil from campus at Chandigarh with the help of aseptic spectula. These soil samples then transferred to the plastic bag. These soil samples were stored at $4^{0} \mathrm{C}$ till further use.

\subsection{Isolation of bacterial culture}

Isolation of bacteria is performed by serial dilution followed by spread plate method. In this process $1 \mathrm{gm}$ of the soil sample were dissolved in the sterilized distilled water to obtain a concentration ranged from $10^{-1}$ to $10^{-4}$. Then $0.1 \mathrm{ml}$ were taken out from sterilized distilled water containing soil sample which then spread through glass rod on the surface of solidify agar plate. These plates were incubate at $37^{\circ} \mathrm{C}$ for $24 \mathrm{hrs}$. The bacterial colonies were streaked to obtain pure culture. Different purified isolates were maintained at $4{ }^{\circ} \mathrm{C}$.

\subsection{Screening of amylase producing bacteria}

Bacteria which produced amylase were screened on the surface of starch-agar plate. These bacteria were streak on the surface of starch-agar plate and incubate at $37{ }^{\circ} \mathrm{C}$ for $24 \mathrm{hrs}$. After incubation, plate was flooded with $1 \%$ of iodine solution. Presence of zone of clearance showed positive results selected for further investigation.

\subsection{Morphological characterization}

The isolated strain was characterized on the basis of size, shape, color, nature of colony and pigmentation.

\subsection{Biochemical characterization}

Selected strain was biochemically characterized using Catalase test oxidase test, indole production, methyl red test, Voges Proskuer test, citrate utilization, Hydrogen sulfide producton, amylase production, Cmcase test, Lipase production and protease test. Fermentation test which were performed by using Lactose, maltose, dextrose, galactose, melibiose, L-arabinose, inulin, dulcitol glycerol, sorbitol, adonitol, rhamnose, melezitose, ONPG, D-arabinose, malonate Utilization, xylose, fructose, raffinose, trehlose, Sodium gluconate, sucrose, mannose, salicin, inositol, mannitol, ribose, cellobiose, esculin hydrolysis, xylitol, sorbose and citrate utilization.

\subsection{Amylase production}

The production medium was inoculated with overnight grown inoculum. For the preparation of inoculum a loop full of bacterial isolate was transferred in $50 \mathrm{ml}$ of inoculum medium. The flask was placed on a rotary shaker incubator at a speed of $150 \mathrm{rpm}$ at $37^{\circ} \mathrm{C}$ for $12 \mathrm{hrs}$. Amylase production was carried out by submerged fermentation. $25 \mathrm{ml}$ of bacterial inoculums was added into $250 \mathrm{ml}$ of the production medium (same as inoculation medium). The flask was placed on a rotary shaker incubator at a speed of $150 \mathrm{rpm}$ at $37{ }^{\circ} \mathrm{C}$ for $24 \mathrm{hrs}$. After incubation, fermented broth was centrifuged at
8000 rpm for $20 \mathrm{~min}$ in a cooling centrifuge. Supernatant was collected which was crude enzyme and used for the estimation of amylase.

\subsection{Optimization of reaction conditions of crude amylase}

\subsection{1. pH optimization}

The $\mathrm{pH}$ of the enzyme is optimized using phosphate buffer of different $\mathrm{pH}$. Phosphate buffer of $\mathrm{pH} 6,7$ and 8 are prepared.

\subsubsection{Temperature optimization}

To find out the optimum temperature at which the enzyme shows maximum activity, enzyme assay is performed at different temperature of incubation. Enzyme activity is checked by incubating at different temperature of $40^{\circ} \mathrm{C}, 50$ ${ }^{\circ} \mathrm{C}, 60{ }^{\circ} \mathrm{C}$.

\subsection{Partial purification of amylase enzyme}

The ammonium sulphate precipitation followed by dialysis was used for partial purification of amylase enzyme. Ammonium sulphate was saturate up to $80 \%$ of $100 \mathrm{ml}$ cell free extract. After overnight incubation, the content was centrifuged at $10000 \mathrm{rpm}$ for $30 \mathrm{~min}$. Supernatant was collected and saturated up to $90 \%$ with ammonium sulphate. Then the content was further centrifuged at $10000 \mathrm{rpm}$ for $20 \mathrm{~min}$ and pellet was collected for further analysis. The enzyme mixture was transferred in a dialysis bag and immersed in phosphate buffer at $4^{\circ} \mathrm{C}$ for $24 \mathrm{hrs}$. buffer was continuously stirred using a magnetic stirrer throughout the process with regular change of buffer.

\subsubsection{Enzyme assay for amylase enzyme}

$1.0 \mathrm{ml}$ of culture broth was taken in test tube and $1.0 \mathrm{ml}$ of substrate (starch) was added in test tube. The test tubes were covered and incubate at $35^{\circ} \mathrm{C}$ for 15 minutes in water bath. Then $2.0 \mathrm{ml}$ DNS reagent was added in each tube to stop the reaction and kept in boiling water bath for 10 minutes. After cooling at room temperature, the absorbance was read at 540 $\mathrm{nm}$ by spectrophotometer.

\section{Results and Discussion}

Amylase, producing organisms like fungi and bacteria are generally isolated from soil and most of the work is focused on the amylase. The present study deals with isolation of amylase producing bacteria from soil. The collected soil samples producing different types of colonies on the surface of nutrient agar after serial dilution (Alariya et al., 2013). The isolated bacterial colonies were analyzed for their colony morphology and Gram's staining (Figure 1). Three bacterial strains were isolated i.e. RT03, RT5, T5. These bacterial strains were tested for amylolytic activity with iodine test. The zone clear is developed around the bacterial colony due the utilization of the starch present in the media by the amylase produced by the bacterium (Haribhau et al., 2015). The RT5 strain produced more amylase enzyme as compare to RT03 and T5. Similar method was also used by Singh, et al 2016 to isolate 5 bacterial strains out of 10, on the basis 


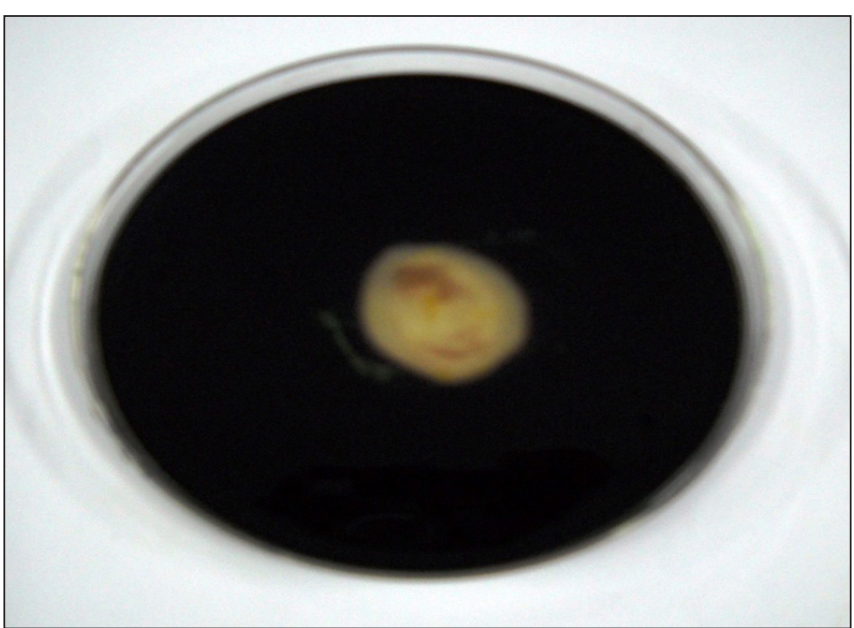

Figure 1: Bacillus sp. showing positive starch hydrolysis

of zone of clearance. The morphological characterization of strain RT5 showed that it is rod shaped bacilli, cream color, raised elevation, entire margin, moderate size and Gram negative in nature (Figure 2). Enzymatic activity of strain RT5 was estimated by Inoculating culture on $50 \mathrm{ml}$ of Luria broth containing $1 \%$ of starch in two flasks and incubates

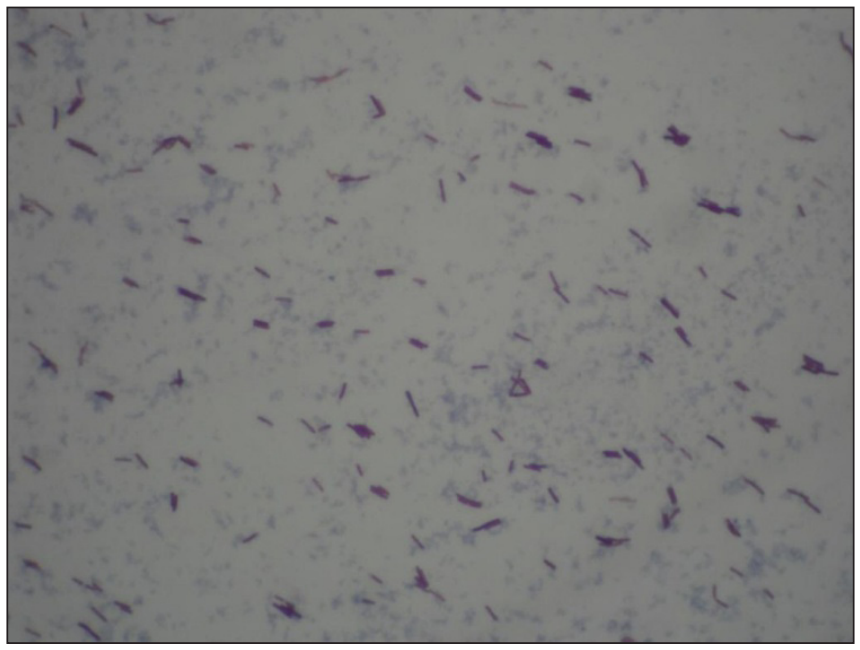

Figure 2: Bacillus sp. showing gram negative nature

at $37^{\circ} \mathrm{C}, 150 \mathrm{rpm}$ for $24 \mathrm{hrs}$. The activity was checked after $48 \mathrm{hrs}$ of incubation. Enzyme shows higher activity at 24 hrs of incubation i.e. $3.34 \mathrm{U} \mathrm{mg}^{-1}$ as compare to $48 \mathrm{hrs}$ of incubation i.e.1.332 $\mathrm{U} \mathrm{mg}^{-1}$. This means that amylase activity decrease from 3.34 to $1.332 \mathrm{U} \mathrm{ml}^{-1}$ as the incubation time increase from 24 to 48 hours at $35 \pm 2{ }^{\circ} \mathrm{C}$ (Table 5). Similar work was done by singh et al 2016 reported decrease in amylase activity from 0.981 to $0.215 \mathrm{U} \mathrm{ml}^{-1}$ as the incubation time increase from 24 to $72 \mathrm{hrs}$ at $35 \pm 2{ }^{\circ} \mathrm{C}$. Hence, $24 \mathrm{hrs}$ broth is taken for enzyme isolation and its characterization. Physiological characterization of RT5 showed negative results for growth at $30^{\circ} \mathrm{C}$ and positive result at $37^{\circ} \mathrm{C}, 50^{\circ} \mathrm{C}$ and $60^{\circ} \mathrm{C}$ (Table 1). For further optimization of enzyme production was carried out for $\mathrm{pH}$ and Temperature. This enzyme produced

\begin{tabular}{lc}
\hline \multicolumn{2}{l}{ Table 1: Physiological characteristics of bacterial strain RT5 } \\
\hline Growth Temperature & Strain RT 5 \\
\hline $30{ }^{\circ} \mathrm{C}$ & -ve \\
$37^{\circ} \mathrm{C}$ & $+\mathrm{ve}$ \\
$50^{\circ} \mathrm{C}$ & $+\mathrm{ve}$ \\
$60^{\circ} \mathrm{C}$ & $+\mathrm{ve}$ \\
\hline
\end{tabular}

maximum activity at $\mathrm{pH} 6$ i.e. $4.08 \mathrm{U} \mathrm{mg}^{-1}$ as compare to $\mathrm{pH}$ 7 and 8 i.e. $2.42 \mathrm{U} \mathrm{mg}^{-1}$ and $1.298 \mathrm{U} \mathrm{mg}^{-1}$ respectively (Figure 3). Mahdavi et al., 2010 and Demirkan, 2011 in Bacillus subtilis showed that this enzyme was optimally active at $\mathrm{pH}$ 6.0. The enzyme showed maximum activity at $50{ }^{\circ} \mathrm{C}$ i. e 0.80 as compare to $40{ }^{\circ} \mathrm{C}$ and $60^{\circ} \mathrm{C}$ i.e. 0.74 and 0.75 respectively (Figure 4). A similar result was also found by Mahdavi et al., 2010; Singh et al., 2016 and Annamalai et al., 2011 in Bacillus

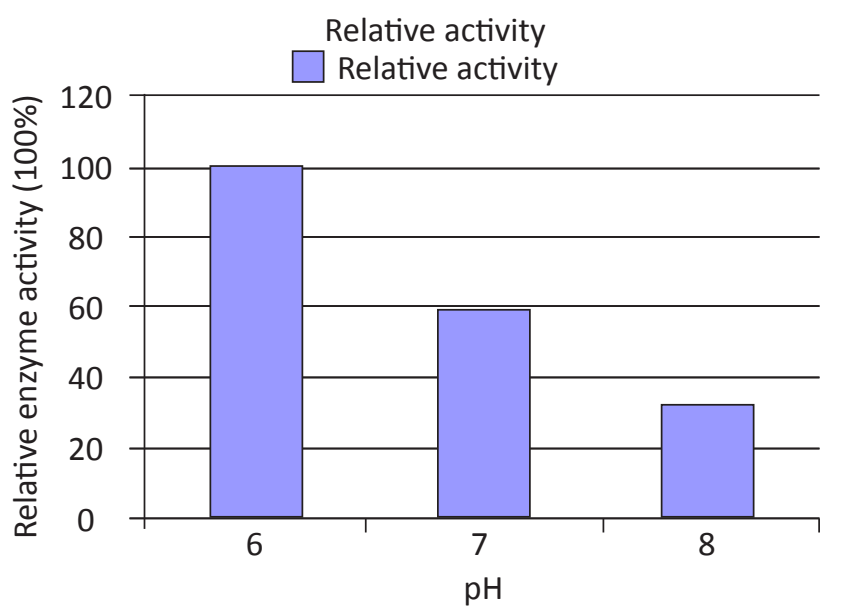

Figure 3: Relative activity of enzyme at different $\mathrm{pH}$

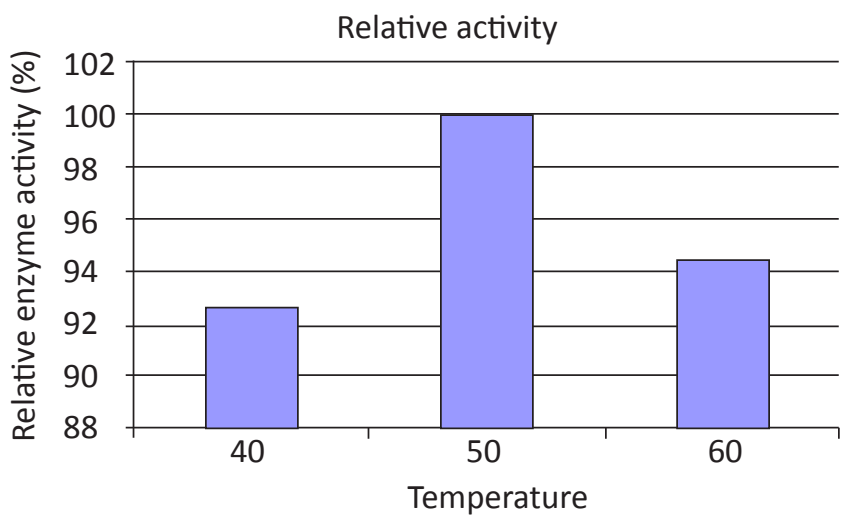

Figure 4: Relative activity of enzyme at different temperature

cereus. Various biochemical tests (Table 2, 3) had been done with RT5 which showed positive result for catalase test, oxidase test, amylase production tests but negative for indole production, Methyl red test, Voges Proskuer test, Citrate utilization, Hydrogen sulfide production, cmcase test, lipase production and protease test. Catalase test, oxidase test and starch hydrolysis were also found positive 


\begin{tabular}{lc}
\hline Table 2: Biological characteristics of bacterial strain RT5 \\
\hline Biochemical characteristics & Characteristic ( -ve / +ve ) \\
\hline Catalase test & + \\
Oxidase test & + - \\
Indole production & - \\
Methyl red test & - \\
Voges Proskuer test & - \\
Citrate utilization & - \\
Hydrogen sulfide producton & + \\
Amylase production & - \\
Cmcase test & - \\
Lipase production & - \\
Protease test &
\end{tabular}

\begin{tabular}{|c|c|c|c|}
\hline $\begin{array}{l}\text { Carbohy- } \\
\text { drate }\end{array}$ & $\begin{array}{c}\text { Character- } \\
\text { istic } \\
\text { (+ve / -ve) }\end{array}$ & Carbohydrate & $\begin{array}{c}\text { Character- } \\
\text { istic (+ve } \\
\text { /-ve) }\end{array}$ \\
\hline Lactose & - & Xylose & + \\
\hline Maltose & + & Fructose & + \\
\hline Dextrose & + & Raffinose & - \\
\hline Galactose & - & Trehalose & + \\
\hline Melibiose & - & Sucrose & + \\
\hline L-Arabinose & - & Mannose & + \\
\hline Inulin & - & $\begin{array}{c}\text { Sodium gluco- } \\
\text { nate }\end{array}$ & - \\
\hline Glycerol & + & Salicin & - \\
\hline Dulcitol & - & Inositol & - \\
\hline Sorbitol & - & Mannitol & + \\
\hline Adonitol & - & Ribose & - \\
\hline Rhamnose & - & Cellobiose & - \\
\hline Melezitose & - & Xylitol & - \\
\hline ONPG test & - & $\begin{array}{l}\text { Esculin Hydro- } \\
\text { Iysis }\end{array}$ & - \\
\hline D-Arabinose & - & $\begin{array}{l}\text { Citrate utiliza- } \\
\text { tion }\end{array}$ & - \\
\hline $\begin{array}{l}\text { Malonate } \\
\text { Utilization }\end{array}$ & - & Sorbose & - \\
\hline
\end{tabular}

by Pokhrel et al., 2013; Patel et al., 2013. Fermentation test with RT5 showed that it is positive for maltose, dextrose, glycerol, xylose, fructose, trehalose, sucrose, mannose and mannitol utilization but negative for lactose, galactose, melibiose, L-arabinose, raffinose, inulin, sodium gluconate, salicin, dulcitol, inositol, adonitol, sorbitol, cellobiose, ribose, rhamnose, xylitol, melezitose, ONPG test, esculin hydrolysis, $\mathrm{D}$-arabinose, citrate utilization, malonate utilization and sorbose test. Biochemical test such as indole test, sugar utilization test, methyl red test, citrate utilization Test, voges proskauer test, starch hydrolysis, catalase test, casein hydrolysis were carried out to find the enzymatic activity of isolated organism by Gowsalya et al., 2014. Microorganism always require specific environment for their growth. So, it is important to know which parameters are important for the growth of a given bacterial taxon. Therefore, one alternative is to take the bacteria back to the environment to grow them, often by moving a portion of the environment into the laboratory (Table 4 and 5).

\begin{tabular}{|c|c|c|}
\hline \multicolumn{2}{|c|}{ Concentration of glucose $\left(\mathrm{mg} \mathrm{ml}^{-1}\right)$} & Absorbance at $540 \mathrm{~nm}$ \\
\hline \multicolumn{2}{|c|}{0.0} & 0.00 \\
\hline \multicolumn{2}{|c|}{0.2} & 0.36 \\
\hline \multicolumn{2}{|c|}{0.4} & 0.68 \\
\hline \multicolumn{2}{|c|}{0.6} & 1.00 \\
\hline \multicolumn{2}{|c|}{0.8} & 1.20 \\
\hline \multicolumn{2}{|c|}{1.0} & 1.70 \\
\hline \multicolumn{3}{|c|}{$\begin{array}{l}\text { Table 5: Production of amylase by strain RT after partial } \\
\text { purification }\end{array}$} \\
\hline SI. No. & Time & Enzyme activity $\left(\mathrm{u} \mathrm{ml}^{-1}\right)$ \\
\hline 1.0 & $0 \mathrm{hrs}$ & 0.00 \\
\hline 2.0 & $24 \mathrm{hrs}$ & 3.34 \\
\hline 3.0 & $48 \mathrm{hrs}$ & 1.332 \\
\hline
\end{tabular}

\section{Conclusion}

From our work on bacterial strain RT5 we concluded that it is an amylase producing bacteria which is rod shaped, gram negative, having cream color, raised appearance, moderate size and showing maximum activity at $\mathrm{pH} 6$ and 50 o C temperature. The bacteria were grown on medium (nutrient agar) containing $1 \%$ starch. Many of the bacterial species reported were not thermostable. But the amylase from the present study is thermosatble. So, the amylase used in present study has various industrial applications.

\section{References}

Arcidiacono, B., liritano, S., Chiefari, E., Brunetti, F.S., Gu, G., Foti, D.P., Brunetti, A., 2014. Cooperation between HMGA1, PDX-1, and MafA is Essential for GlucoseInduced Insulin Transcription in Pancreatic Beta Cells. Front Endo-crinol (Lausanne) 5, 237.

Alariya, S.S., Sethi, S., Gupta, S., Gupta, B.L., 2013. Amylase activity of a starch degrading bacteria isolated from soil. Archives of Applied Science Research 5(1), 15-24.

Annamalai, N., Thavasi, R., Vijayalakshmi, S., Balasubramanian, 
T., 2011. Extraction, Purification and Characterization of Thermostable, Alkaline Tolerant a-Amylase from Bacillus cereus. Indian Journal of Microbiology 51(4), 424-429.

Behal, A., Singh, J., Sharma, M.K., Puri, P., Batra, N., 2006. Characterization of alkaline -amylase from Bacillus $\mathrm{sp}$. $A B$ 04. International Journal of Agriculture and Biology 08, 80-83

Dehkordi, M.M., Javan, F.A., 2012. Application of alphaamylase in biotechnology. Journal of Biology and Today's world 1, 39-50.

Demirkan, E., 2011. Production, purifi cation, and characterization of $\alpha$-amylase by Bacillus subtilis and its mutant derivates. Turkish Journal of Biology 35, 705-712.

Gowsalya, A., Ponnusami, V., Sugumaran, K.R., 2014. Isolation of Bacteria from Soil sample for ExoPolysaccharide production. International Journal of Chem Tech Research CODEN (USA) 6, 2925-2928.

Haribhau, K.K., Patil, V. B., Patil, A.P., 2015. isolation, screening and optimization of microorganism producing amylase. World journal of pharmacy and pharmaceutical sciences 4, 1415-1425.

Kumar, M.N., Karthikeyan, S., Jayaraman, G., 2013. Thermostable alpha-amylase enzyme production from Bacillus laterosporus: Statistical optimization, purification and characterization. Biocatalysis and Agricultural Biotechnology 2, 38-44.

Mahdavi, A., Sajedi, R.H., Rassa, M., Jafarian, V., 2010. Characterization of an $\alpha$-amylase with broad temperature activity from an acid-neutralizing Bacillus cereus strain. Iranian journal of biotechnology 8, 103-111.

Patel, J., Meena, R.K., Sao, S., Dubey, S.K., Shukla, P., 2014. Amylase degrading bacteria from soil and their RAPD profiling. International journal of current Microbiology and applied sciences 3, 55-63
Pokhrel, B., Wanjare, P., Singh, S., Purushotham, B., Kumara, S.M., 2013. Isolation, screening and characterization of promising $\alpha$-amylase producing bacteria from sewage enriched soil. International Journal of Advanced Biotechnology and Research 4, 286-290.

Raul, D., Biswas, T., Mukhopadhyay, S., Das, S.K., Gupta, S., 2014. Production and Partial Purification of Alpha Amylase from Bacillus subtilis (MTCC 121) Using Solid State Fermentation. Biochemistry Research International, doi.org/10.1155/2014/568141, 1-5.

Sani, I., Abdulhamid, A., Bello, F., Yahaya, M., Bagudo, A. I., 2014. Isolation, partial purification and characterization of $\alpha$-amylase from Bacillus subtilis. Journal of Microbiology and Biotechnology Research 4(1), 49-54.

Singh, P., Kumari, P., 2016. Isolation and characterization of amylase producing Bacillus spp. from selected soil sample. International Journal of Research in Biosciences 5, 24-29.

Singh, P., Rani, A., 2014. Isolation and Partial Characterization of Amylase Producing Bacillus sp. from Soil. International Journal of PharmTech Research 6, 2064-2069.

Singh, R.N., Bahuguna, A., Chauhan, P., Sharma, V.K., Kaur, S., Singh, S.K., Khan, A., 2016. Production, purification and characterization of thermostable $\alpha$-amylase from soil isolate Bacillus sp. strain B-10. Journal of Bioscience and Biotechnology 5(1), 37-43

Singh, S., Sharma, V., Soni, M.L., 2011. Biotechnological applications of industrially important amylase enzyme. International Journal of Pharma and Bio Sciences 2, 486-496.

Sivaramakrishnan, S., Gangadharan, D., Nampoothiri, K. M., Soccol, C. R., Pandey, A., 2006. $\alpha$-Amylases from Microbial Sources-An Overview on Recent Developments. Food Technol. Biotechnol 44 (2), 173-184. 